Jurnal Widya Sastra Pendidikan Agama Hindu, Vol 4, No. 1, 2021

ISSN: 2656-7466

\title{
MODEL MODERASI BERAGAMA BERBASIS KEARIFAN LOKAL DI DESA PEGAYAMAN KABUPATEN BULELENG
}

\author{
I Putu Suarnaya \\ suarnayaiputu@gmail.com
}

\begin{abstract}
ABSTRAK
Penelitian ini bertujuan Mengidentifikasi Model Moderasi Beragama Berbasis Kearifan Lokal Di Desa Pegayaman Kabupaten Buleleng? Subyek penelitian ini adalah masyarakat Desa Pegayaman, teknik pengambilan sampel digunakan dalam penelitian ini adalah purposive snowball sampling. Tekhnik pengumpulan data yang digunakan adalah metode observasi, wawancara dan dokumentasi. Sedangkan analisis data yang digunakan adalah analisis deskriptif kualitatif. Hasil penelitian ini menunjukkan bahwa: Sejarah desa Pegayaman tidak bisa lepas dari pemimpin Raja Buleleng bernama Anglurah Kibarak Panji Sakti. Nama Pegayaman diambil dari pohon gatep (gayam) atau diambil dari nama sebilah keris yaitu gayaman yang ada pada jaman kerajaan Mataram.Terkait dengan analisis yang berhubungan dengan identifikasi model moderasi keagamaan berbasis kearifan lokal di Desa Pegayaman terimplementasi dengan baik pada delapan aspek aktivitas masyarakat yaitu: 1) pemerintahan desa, 2) kepemimpinan, 3) upacara persembahan, 4) keyakinan, 5) budaya berkomunikasi, 6) personal, 7) budaya dan seni, 8) tradisi ngejot semuanya merupakan akulturasi budaya Hindu-Islam yang terproses ratusan tahun silam dari jaman kerajaan Ki Barak Panji Sakti tanpa henti sampai sekarang. Moderasi beragama dan budaya Hindu-Islam perlu diimplementasikan secara kontinyu berkesimbangungan untuk dapat menjalin kesatuan dan persatuan masyarakat menuju masyarakat aman, damai, sejahtera dan harmonis.
\end{abstract}

Kata Kunci : moderasi keagamaan dan kearifan lokal

\section{ABSTRACT}

This research aims to identify the Religious Moderation Model Based on Local Wisdom in Pegayaman Village, Buleleng Regency? The subjects of this study were the people of Pegayaman Village. The sampling technique used in this study was purposive snowball sampling. The data collection techniques used were observation, interview and documentation methods. While the data analysis used is descriptive qualitative analysis. The results of this study indicate that: The history of Pegayaman village cannot be separated from the leader of the King of Buleleng named Anglurah Kibarak Panji Sakti. The name Pegayaman is taken from the gatep tree (gayam) or taken from the name of a keris, namely the style that existed during the Mataram kingdom era. Related to the analysis related to the identification of religious moderation models based on local wisdom in Pegayaman Village which is well implemented in eight aspects of community activities, namely: 1) village administration, 2) leadership, 3) offering ceremonies, 4) belief, 5) communication culture, 6) personal, 7) culture and art, 8) the ngejot tradition are all acculturations of Hindu-Islamic culture processed hundreds of years ago from Ki Barak Panji Sakti's kingdom era without stopping until 
now. The moderation of religion and Hindu-Islamic culture needs to be implemented continuously in a balanced way to be able to forge unity and community unity towards a safe, peaceful, prosperous and harmonious society.

Keywords: religious moderation and local wisdom

\section{PENDAHULUAN}

Pegayaman merupakan salah satu desa di Bali yang terletak di daerah pegunungan tepatnya di kecamatan Sukasada Kabupaten Buleleng Bali. Desa ini memiliki keunikan kalau dibandingkan dengan desa lain yang ada di Kabupaten Buleleng. Masyarakatnya sangat ramah dan dapat hidup rukun dengan masyarakat Hindu yang mengelilingi desa mereka. Tata letak desa berpengaruh terhadap interaksi sosial masyarakat disekitarnya. Agama Hindu dan Islam di desa Pegayaman mampu hidup damai berdampingan dan menjalin persaudaraan dan kerukunan beragama. Kerukunan mengandung makna hidup dalam kebersamaan. Oleh karena itu, membangun semangat dan sikap kebersamaan di antara penganut agama tetap harmonis tidak bisa lepas dari model moderasi beragama. Moderasi berasal dari kata moderat, dalam KBBI (2000:751) kata moderat dapat diartikan sebagai pengurangan kekerasan dan penghindaran ekstrimesme. Moderasi beragama adalah proses memahami sekaligus mengamalkan ajaran agama secara adil dan seimbang, agar terhindar dari perilaku yang menyimpang yang tidak ada di ajarkan di dalam agama.

Dalam hal ini adanya interaksi social religius dalam kehidupan beragama. Hubungan sosial atau relasi sosial akan terjadi apabila ada jalinan interaksi yang terjadi antara perorangan dengan perorangan atau kelompok dengan kelompok atas dasar status (kedudukan) dan peranan sosial. Hubungan sosial atau relasi sosial adalah hubungan antara dua atau lebih individu, di mana tingkah laku yang satu mempengaruhi, mengubah atau memperbaiki tingkah laku individu yang lain dan sebaliknya. Dengan demikian model moderasi keagamaan di desa Pegayaman dapat persepsikan melalui tradisi kegiatan masyarakat yang ada di desa Pegayaman seperti : Moderasi Beragama dalam Perspektif Pemerintahan Desa; Moderasi Beragama dalam Perspektif Kepemimpinan; Moderasi Beragama Dalam Perspektif Upacara/Persembahan; Moderasi Beragama dalam Perspektif Keyakinan; Moderasi Beragama Dalam Perspektif Budaya Berkomunikasi; Moderasi Beragama Dalam Perspektif Budaya dan Seni; Moderasi Beragama Dalam Perspektif Personal (Identitas Diri); dan Moderasi Beragama dalam Perspektif Tradisi Ngejot.

\section{METODE PENELITIAN}

Penelitian ini dirancang dengan penelitian kualitatif, teknik penentuan informan yang digunakan adalah purposive snowball sampling (Sugiyono, 2012), pengumpulan data yang digunakan dalam penelitian ini adalah: observasi partisipasi, wawancara, dan pencatatan dokumen (Bogdan, R.C. \& Taylor, S.J.,1973; Spradley,1980; Strauss, Anselm I dan Yuliet Corbin, 1990; Sugiyono, 2012; dan analisis data adalah deskriptif kualitatif dengan analisis data menggunakan model FGD (Focus Group Discuscion) (Morgan,1997; \& Bungin, 2003:131). 


\section{HASIL DAN PEMBAHASAN}

Implementasi Moderasi Beragama dalam kehidupan sehari-hari dapat memunculkan akulturasi budaya berbasis muatan local seperti di Desa Pegayaman. Akulturasi budaya adalah bertemunya dua atau lebih kebudayaan yang berbeda melebur menjadi satu menghasilkan kebudayaan baru tanpa meninggalkan identitas yang aslinya. Terkait dengan penelitian ini akulturasi dilihat dari budaya budaya Bali (Hindu) dan budaya Islam (Muslim) di Desa Pegayaman. Budaya Bali bagi orang Bali bersumber dari ajaran Agama Hindu yang terlihat dalam setiap aspek perilaku kehidupan bermasyarakat. Demikian juga bagi masyarakat di Desa Pegayaman, Agama Islam yang dianutnya menjadi dasar perilaku mereka. Oleh karena itu interaksi kebudayaan yang berbeda secara sosio kultur religius tersebut sebagai penciri bagi masyarakat di pegayaman. Moderasi Beragama di Desa Pegayaman dapat dipersepsikan dari berbagai unsur aktivitas masyarakat. Dari penelitian yang dilakukan maka aspek moderasi beragama Bali (Hindu) dengan Islam di Desa Pegayaman dalam konteks persaudaraan atau menyama-braya (Landrawan, I Wayan, dkk. 2013) dapat diketahui dari paparan di bawah ini.

\section{a) Moderasi Beragama dalam Perspektif Pemerintahan Desa}

Moderasi Beragama dalam mengatur kehidupan bermasyarakat di desa Pegayaman secara legal formal dipimpin oleh kepala desa yang disebut juga "Perbekel" Desa Pegayaman. Perbekel sebagai pimpinan tertinggi di desa yang sehari-harinya masyarakat setempat menyebut "pak mekel" (sebagai panggilan keseharian kepada bapak Kepala Desa). Nama "pak mekel" ini mengandung makna moderasi keagamaan "menyama-braya" dimana panggilan "pak mekel" merupakan panggilan yang diucapkan oleh orang Bali (Hindu). Ternyata budaya tersebut juga digunakan oleh masyarakat di desa Pegayaman. Dengan menggunakan sebutan pak mekel dapat mengangkat rasa persaudaraan yang tinggi diatara masyarakat setempat (intern) dan terhadap masyarakat di luar desa yaitu masyarakat Buleleng. Rasa persaudaraan memunculkan rasa hormat, rasa segan, setia, merasa sehati, senasib seperjuangan untuk membangun Buleleng. Model moderasi keagamaan berbasis kearifan lokal dalam pemerintahan di desa Pegayaman sejalan dengan dengan pendapat ahli bernama Bass dalam Yukl (2010:313) sistem pemerintahan transformasional merupakan suatu keadaan dimana para pengikut dari seorang pemimpin transformasional merasa adanya kepercayaan, kekaguman, kesetiaan, dan hormat terhadap pemimpin tersebut, dan mereka termotivasi untuk melakukan lebih dari pada yang awalnya diharapkan mereka.

Dalam konsep budaya Bali (Hindu) dikenal dengan istilah "Sagalak, Saguluk, Salunglung, Sabayantaka paras paros sarpanaya" ( suatu tekad bulat dan saling mengisi dalam menghadapi masalah hidup dan kehidupan bersama, rukun dan damai) (Ngurah, 2010:174). Moderasi keagamaan seperti ini sejalan dengan teori penyesuaian sosial dari Schneiders (1964), yang menyatakan bahwa penyesuaian sosial merupakan kemampuan untuk bereaksi secara efektif dan sehat terhadap situasi, realitas dan relasi sosial sehingga tuntutan hidup bermasyarakat dipenuhi dengan cara yang dapat diterima dan memuaskan. Salah satu aspek penyesuaian sosial adalah (recognition) yaitu menghormati dan menerima hak-hak orang lain dalam hal ini individu tidak melanggar hak-hak orang lain yang berbeda dengan 
dirinya. Penghormatan atas hak individu moderasi hubungan sosial antar individu dapat terjalin dengan harmonis. Demikian halnya dengan panggilan mekeladalah hak masyarakat yang legal karena bahasa adalah budaya yang diwarisinya dari leluhurnya mereka. Oleh karena sebutan mekel sebagai budaya yang dapat diterima oleh orang Bali (Hindu) dan Muslim maka sebutan mekel berfungsi perekat moderasi keharmonisan. Sebutan mekel lebih bernuasa local genius kalau dibandingkan dengan lurah (untuk Kepala Kelurahan), dan kades (untuk Kepala Desa). Sebutan pak mekel di Desa Pegayaman mengandung makna bahwa ada kedekatan secara psikologis dengan budaya Bali (Hindu). Dalam tata pemerintahan di desa Pegayaman ada bagian yang dinamai "Banjar". Banjar adalah Banjar adalah kesatuan wilayah dan orang /tenaga yang dapat digerakkan secara cepat dan praktis (Astika, I Wayan Suwena \& Ni Nyoman Ayu Candradewi,1986:9). Pendapat lain menyatakan banjar adalah subsistem dari desa yang merupakan kesatuan sosial atas dasar ikatan (Suarnaya, 2002:11).

Desa Pegayaman juga mengadopsi budaya Bali yaitu banjar dalam memberi nama bagian pemerintahan di Desanya. Tak satupun masyarakat desa Pegayaman yang komplin atas penggunaan nama yang mengadopsi budaya Bali (Hindu), bahkan sangat bangga dan mereka menyebut warisan budaya leluhurnya. Fakta ini sesuai dengan teori Hegemoni menurut Gramsci 1891,(dalam Ngurah, 2010:32) yang menyatakan bahwa hegemoni merupakan alat kontrol kesadaran yang dapat digunakan kelompok penguasa. Hegemoni adalah bentuk penguasaan pada kelompok tertentu dengan menggunakan kepemimpinan intelektual dan moral secara consensus serta menyepakati nilai-nilai ideologis penguasa. Perilaku kepemimpinan yang diterapkan oleh perbekel Pegayaman menggunakan model pendekatan autentik budaya Bali sebagai warisan leluhur (kearifan local). Pernyataan ini menggunakan bahasa yang sederhana dapat dipahami oleh masyarakat umum. "Warisan leluhur" mempunyai makna sakral bagi masyarakat Pegayaman, artinya masyarakat Pegayaman mempunyai keyakinan bahwa leluhur mereka mempunyai pengaruh dogmatis yang pantang dilanggar. "Dogma" tersebut diturunkan secara lisan namun sampai saat ini sangat fungsiaonal. Banyak tradisi-tradisi adat yang diterapkan lisan (dogma) yang dalam budaya Bali dikenal dengan gugontuwon. Di balik dogma tersebut ada fungsi pelestarian atau pengejawantahan pemerintahan menuju persatuan, yang harmonis interen dan eksteren (Hindu-Islam). Nama Banjar sebagai budaya lokal Bali juga disenangi oleh warga. Rasa senang dan peduli terhadap banjar mereka. Desa Pegayaman memiliki slogan: "WARGE SAMI NGIRING MEKARYE AMPUNANG AKEH WICARE" (warga semua mari bekerja jangan banyak bicara). Slogan ini memberi inspirasi kepada masyarakat Desa Pegayaman untuk giat bekerja tidak banyak bicara.

Kepala banjar dinas dinamai "Kelian" dan juga disebut Kepala Dusun (Kadus) oleh masyarakat desa Pegayaman. Kelian adalah nama yang digunakan oleh pemerintahan desa pakraman di Bali serta beberapa ketua atau kepala organisasi tradisional di Bali. Adopsi penggunaan budaya Bali (Hindu) seperti yang dipaparkan di atas, menunjukkan rasa persaudaraan internal dan eksternal. Budaya Bali sebagai alat hegemoni untuk mempererat menyama-braya tertata secara lisan dan mampu bertahan sampai saat penelitian ini dilaksanakan. Teori strukturalis fungsional Robert K. Merton (dalam Triguna, 2000:30) menyatakan bahwa Structured Funciont Primitive Society memberikan struktur yang terdiri dari seperangkat hubungan di antara entitasentitas unik. Kesinambungan struktur dipertahankan dan dilestarikan yang diwujudkan 
oleh unit-unit di dalamnya. Selanjutnya dinyatakan fungsi identik dengan guna yang dikaitkan dengan kebutuhan psikologi, fungsi adalah kegunaan dari instansi dalam rangka memenuhi kebutuhan psikologi individu-individu masyarakat. Teori fungsional stuktural menekankan pada keteraturan (order) dan mengabaikan konflik serta perubahan-perubahan yang terjadi dalam masyarakat beragama. Menurut teori ini masyarakat agama merupakan suatu sistem sosial yang terdiri atas bagian-bagian satu sama lain yang saling tersetruktur/berhubungan, menyatu dalam keseimbangan. Perubahan yang terjadi pada satu bagian akan membawa perubahan pada bagianbagian lainnya. Dasar berpikir setiap struktur dalam sistem sosial yang disfungsional, maka struktur dalam sistem sosial itu akan menghilang dengan sendirinya. Moderasi Beragama dalam konteks budaya Bali (Hindu) dengan Muslim di Desa Pegayaman dalam menata kepemimpinan desa yang pengejawantahannya model lisan (gugon tuwon) ternyata masih tersetruktur dari berbagai aspek antara lain; aspek generasi ke generasi berikutnya yang diturunkan dengan sistem pemodelan atau contoh dari orang tua kepada ana - anak mereka, aspek organisasi formal (pemerintah desa dinas dan desa pakraman) organisasi non-formal (organisasi pemuda, sosial keagamaan) dan lain-lainnya.

Berdasarkan paparan di atas dapat dinyatakan model Moderasi Beragama yang dipersepsikan dalam perspektif pemerintahan desa memberikan gambaran yang jelas bahwa kehidupan masyarakat di desa Pegayaman memegang teguh tradisi nenek moyang dengan menghormati, mengagumi serta mempercayai seorang pemimpin dengan sebutan pak mekel (untuk seorang kepala desa) serta penggunaan nama kelian, banjar dan tempekan.

\section{b) Moderasi Beragama dalam Perspektif Kepemimpinan}

Model moderasi dalam perspektif kepemimpinan yang dijadikan panutan oleh pemimpin formal (Perbekel beserta jajarannya) maupun pemimpin non formal yaitu pemimpin adat (Penghulu) serta tokoh-tokoh adat adalah gaya kepemimpinan Raja Buleleng yaitu Anglurah Kibarak Panji Sakti. Masyarakat Pegayaman memandang tokoh Anglurah Kibarak Panji Sakti adalah pemimpin yang; kreatif-proaktif, cerdas, nasionalis, demokratis, berbudaya, spiritual, ber- Bhineka Tunggal Ika. Interaksi kehidupan bermasyarakat pada waktu itu sering dikenal sebutan; menyama Selam sebutan orang Bali (Hindu) kepada saudaranya yang Muslim dan menyama Bali (Hindu) sebutan orang Muslim kepada saudaranya orang Bali (Hindu). Saling isi dan memberi pengaruh budaya merupakan proses yang membutuhkan waktu dan ruang. Waktu terproses dalam hitungan lama bahkan bertahun-tahun untuk dapat saling menerima budaya. Penerimaan budaya juga membutuhkan sistem sosial yang meliputi: pengenalan nilai sosial, pemahaman, penyesuaian sampai pada pengaktualisasian nilai. Sejalan dengan teori sistem sosial menurut Pearsons (dalam Beilharz, 2005) menyatakan bahwa sistem sosial berawal pada interaksi tingkat mikro antara ego dan alter-ego yang didefinisikan sebagai bentuk sistem sosial paling dasar, serta gambaran sistem interaksi ini tercermin dalam bentuk-bentuk yang lebih kompleks yang dilakukan oleh sistem sosial. Beilharz, memberikan batasan sistem sosial yakni merupakan sejumlah orang yang berhubungan dengan timbal baliknya lebih bersifat konstan. Artinya masyarakat kedua komunitas tersebut masih eksis mengimplementasikan konsep tersebut dalam kehidupan sehari-hari. Wujud implementasinya berupa; pergaulan, interaksi sosial dalam berbagai aspek seperti: politik, ekonomi, sosial, budaya dan seni (poleksosbud) untuk membangun desa. 
Perbekel desa Pegayaman secara tegas menyatakan konsep Asta Bharata juga memberi inspirasi dalam kepemimpinan namun maknanya disesuaikan dengan budaya Muslim. Hal ini dinyatakan beliau dalam Lambang Desa Pegayaman dimana dalam lambang tersebut ditulis gelung hias di bawah atap Masjid berjumlah delapan, bermakna delapan orang prajurit Belambangan / Mataram masuk ke Pegayaman. Delapan prajurit tersebut memiliki sifat kepemimpinan seperti Asta Bharata (Profil Desa Pegayaman, 2015).

Perbekel Pegayaman berapiliasi pada simbol Asta Bharata yaitu 8 sifat kepemimpinan Hindu sebagai lambang kekuatan, namun dimodifikasi / dianalogkan sama dengan 8 orang prajurit Belambangan / Mataram yang masuk ke Pegayaman ketika mengawal Raja Buleleng. Sejalan denga teori simbol dari Langer (dalam Littlejohn \& Karena A, Foss, 2014:153), dijelaskan bahwa simbol mengandung arti: untuk sesuatu yang menggambarkan sesuatu, khususnya untuk menggambarkan sesuatu yang in material, abstrak, suatu ide, kualitas, tanda-tanda suatu objek, proses dan lain- lain yang dimediasikan oleh konsepsi, simbol, dan bahasa. Manusia berinteraksi dengan lingkungannya tidak dapat lepas dari pikiranya, simbol dapat memberikan arahan bagi perhatian yang pemilihan alat-alat tertentu atau menentukan cara tersebut yang dipakai untuk mencapai tujuannya. Delapan prajurit masingmasing memiliki sifat sebagai berikut. Indra Brata, Yama Brata, Surya Brata, Candra Brata, Bayu Brata, Kuwera Brata, Baruna Brata, Agni Brata. Secara teoritik sesuai teori simbol bahwa otak manusia menangkap objek (dalam hal ini 8 Prajurit) kemudian diolah menjadi ide (ideologi) menjadi Asta Bharata model Desa Pegayaman (Muslim). Dapat dipahami bahwa Belambangan adalah kerajaan yang kena pengaruh kerajaan Hindu Majapahit.

\section{c) Moderasi Beragama Dalam Perspektif Upacara/Persembahan}

Upacara persembahan dalam budaya Bali (Hindu) identik dengan yadnya yang dilaksanakan pada hari raya seperti: Galungan, Kuningan, Nyepi dan sejenisnya. Namun dalam pandangan umat Muslim di Desa Pegayaman "upacara persembahan" mengarah pada perayaan atau peringatan hari raya seperti: hari raya Maulid, Idul Adha, Idul Fitri dan sejenisnya. Selanjutnya di kedua belah pihak Hindu-Muslim berpendapat bahwa hari-hari tersebut adalah hari raya besar keagamaan. Kehidupan sosial masyarakat krama Bali dan nyama Muslim yang berbeda iman di Desa Pegayaman nampak rukun-rukun dan harmonis. Kerukunan ini terkemas dalam budaya keseharian mereka yang diwarisinya dari leluhur mereka. Persembahan merupakan bentuk perilaku yang dikaitkan dengan keyakinan atau keagamaan. Fenomena budaya dalam bentuk perilaku moderasi beragama menyama-braya bagi masyarakat di Desa Pegayaman berakar pada konsep keimanan antara dua komunitas Hindu- Muslim. Seperti makna yang terkandung di balik nyama Bali (Hindu) dan nyama Islam dan lain-lain. Salah satu makna yang bisa ditangkap dari pernyataan di atas bahwa ada pengakuan saudara untuk orang lain. Banyak lagi perilaku HinduMuslim yang identik namun berbeda dalam pemaknaan. Hal ini sesuai dengan teori akulturasi dari Koentjaraningrat,2009:203) menyatakan akulturasi sebagai proses sosial yang timbul bila suatu kelompok manusia dengan suatu kebudayaan tertentu dihadapkan dengan unsur-unsur dari suatu kebudayaan asing dengan sedemikian rupa, sehingga unsur-unsur kebudayaan asing itu lambat laun diterima dan diolah ke dalam kebudayaan sendiri tanpa menyebabkan hilangnya kepribadian kebudayaan itu sendiri. 
Dalam hal ini terdapat perbedaan antara bagian kebudayaan yang sukar berubah dan terpengaruh oleh unsur-unsur kebudayaan asing (covert culture), dengan bagian kebudayaan yang mudah berubah dan terpengaruh oleh unsur- unsur kebudayaan asing (overt culture). Covert culture misalnya: 1) sistem nilai-nilai budaya, 2) keyakinan-keyakinan keagamaan yang dianggap keramat, 3) beberapa adat yang sudah dipelajari sangat dini dalam proses sosialisasi individu warga masyarakat, dan 4) beberapa adat yang mempunyai fungsi yang terjaring luas dalam masyarakat. Sedangkan overt culture misalnya kebudayaan fisik, seperti alat-alat dan bendabenda yang berguna, tetapi juga ilmu pengetahuan, tata cara, gaya hidup, dan rekreasi yang berguna dan memberi kenyamanan. Jika temuan penelitian dihubungkan dengan teori akulturasi di atas terjadi proses sosial (asimilasi) budaya Hindu-Islam perspektif persembahan. Ke dua kelompok memiliki budaya yang berasimilasi menjadi budaya baru yang disebut dengan akulturasi. Budaya akulturasi yang terbentuk masih dalam ranah kesamaan pola/model, sedangkan maknanya masih berbeda. Kesamaan pola/model terbentuk dalam proses overt culture atinya budaya yang bisa berubah karena terjadi interaksi sosial. Budaya yang bisa berubah seperti: adat/kebiasaan, tata cara, gaya hidup dan lain-lain. Yang sulit berubah adalah tata nilai, keyakinan. Adanya kesamaan pola/model dalam merayakan hari keagamaan di desa Pegayaman disebabkan adanya proses penyerapan nilai budaya lain dan bersifat fungsional di luar budaya Islam. Tata nilai dan keyakinan yang berbeda disebabkan karena ke dua aspek tersebut sangat fundamental secara teoritik disebut covert culture.

Ada beberapa budaya yang dalam konteks moderasi beragama telah dilakoni selama bertahun-tahun, salah satu diantaranya adalah pada saat mereka merayakan hari keagamaan. Hari raya Maulid maupun Idul Fitri sebagai hari besar Agama Islam pada masyarakat Pegayaman dalam konteks menyamabraya identik dengan perayaan hari raya Galungan-Kuningan, Hari Raya Nyepi pada masyarakat yang beragama Hindu di Bali. Antusias masyarakat dalam menyambut datangnya hari besar tersebut tercermin dari persiapan yang dilakukan oleh masyarakat muslim sejak beberapa hari menjelang hari $\mathrm{H}$. Persiapan yang dilakukan pada saat menjelang perayaan Maulid ataupun Idul Fitri dilihat dari budaya sangat mirip tetapi berbeda dalam makna yang dikaitkan dengan keyakinan masing-masing. Adapun tahapantahapn yang mirip dengan perayaan upacara Galungan-Kuningan yang dilakukan oleh nyama muslim di Desa Pegayaman adalah sebagai berikut. Tahap pertama adalah penapean dimana masyarakat membuat tape yang dibuat dari ketan, esok harinya penyajaan; masyarakat membuat jaje uli dari bahan ketan, selanjutnya penampahan pada tahapan ini masyarakat menyemblih (nampah) kambing/sapi, dan esok harinya adalah puncak acara (Maulid). Rangkaian upacara ini sangat mirip dengan upacara Agama Hindu di Bali sebagai bukti kuatnya moderasi beragama budaya yang mempererat persaudaraan Hindu-Islam. Tape dan jaje uli yang dibuat dari bahan ketan sama dengan budaya Bali (Hindu) sedangkan penampahan masyarakat Pegayaman menyembelih kambing/sapi sedangkan Agama Hindu menyembelih babi. Disini terjadi akulturasi budaya Bali (Hindu) terhadap budaya masyarakat Muslim Desa Pegayaman.

Masyarakat Muslim di Desa Pegayaman juga mengenal istilah doa syukuran atas keberhasilan pertanian/panen yang dilaksanakan dua kali dalam setahun yang dilaksanakan di Masjid dan di sumber-sumber air. Doa syukuran ini merupakan rasa syukur dan terimakasi kepada Tuhan yang telah memberi anugrah berupa hasil 
panen. Doa syukuran juga ditujukan kepada sang pencipta (Tuhan) agar masyarakat Desa Pegayaman dapat mencapai kesejahteraan dan kebahagiaan. Dalam Agama Hindu persembahan tersebut identik dengan upacara seperti: tumpek Pengatag, tumpek Kandang yang memohon kepada Tuhan agar tanaman berhasil melimpah dan binatang piaraan tumbuh dan berkembang untuk kesejahteraan dan kebahagiaan. Memahami budaya masyarakat Desa Pegayaman tercermin dalam perayaan Maulid di Desa Pegayaman Kecamatan Sukasada Kabupaten Buleleng. Sebagai anggota Subak, mereka juga melakukan upacara-upacara dalam bidang pertanian, terutama untuk padi. Mulai dari menanam sampai panen. Bedanya, tradisi ini dilakukan dengan cara mengaji di mushola-mushola atau dekat sumber mata air atau sawah. Tiap selesai panen, misalnya, petani Pegayaman melaksanakan tradisi membaca (Kitab Aqidatulawam Abda'u), syukuran dengan membuat sate gempol dari daging sapi serta membuat ketupat. Sebelum bersantap menikmati makanan ini, petani terlebih dulu membaca puji-pujian dalam Bahasa Arab. Kegiatan upacara subak tersebut memiliki kesamaan dengan uapacara subak di Bali (Hindu) orang di Bali juga melaksanakan tahapan upacara mulai sejak menanam padi (nuasanin), menjelang panen (upacara ngerasakin) dan pasca panen upacara (mantenin). Tak hanya dalam ritual atau ibadah. Pengaruh budaya Bali pun masih terlihat dimana masih diterapkannya Subak, tidak hanya sebagai sebuah kelompok pengairan, tetapi juga sebagai sebuah budaya. Sebagian besar warga Pegayaman bekerja sebagai petani padi, kopi, maupun cengkeh.

Disamping perayaan syukuran atas keberhasilan pertanian masyarakat Desa Pegayaman juga mempunyai beraneka ragam budaya yang menggunakan sarana mirip budaya Bali (Hindu). Sarana yang digunakan dapat dilihat dalam perayaan Maulid. Perayaan Maulid di Desa Pegayaman sangat meriah dan sering disebut dengan pesta budaya. Sepekan penuh masyarakat di sana bergembira menyambut kelahiran Nabi Muhammad SAW. Tradisi mengarak sokok: sokok base dan sokok taluh, kemudian mengaraknya pawai keliling desa, dilanjutkan dengan pergelaran pencak silat setiap sore. Tradisi ini mirip dengan upacara ngusaba di beberapa daerah di Bali khusunya di Buleleng yang juga mengarak hasil-hasil panen yang bertujuan untuk keselamatan dan kesejahteraan masyarakat. Responden menjelaskan perayaan Maulid ini dilaksanakan dengan penuh keyakinan dan kehidmatan dan jika dilakukan dengan ketulusan hati diyakini akan mendapat berkah. Sokok adalah sarana upacara desa yang sangat penting dan khas. Sangat mungkin sokok berasal dari Bahasa Jawa, soko, yang berarti tiang. Pada sokok base menandai kuatnya peran kebudayaan Bali. Sokok base sangat mirip dengan pajegan yang dibuat masyarakat Hindu Bali yang dijadikan sarana upacara ke pura pada hari-hari upacara tertentu. Sarana base (daun sirih), kembang, buah-buahan, dan telor adalah product local genius Bali yang berasal dari hasil pertanian dan peternakan. Usai membaca doa, rangkaian sokok base dibongkar, kembang dan daun sirih dibawa pulang, diletakkan di dinding rumah atau di sawah. Konon rangkaian daun sirih dan kembang bekas sokok base itu bisa mendatangkan berkah untuk rumah atau sawah. Tradisi ini juga mirip dan banyak dijumpai dalam upacara Agama Hindu, dimana sehabis upacara ada beberapa sarana upacara yang dibiarkan atau ditaruh di tempat tertentu atau pun di taruh di rumah seperti tegteg daksina, dan sejenisnya karena diyakini akan memberikan keselamatan dan kesejahteraan. Telor sebagai salah satu sarana "pajegan" yaitu sokok mempunyai makna kulit telor paling luar yang keras merupakan simbol dari masjid, putih telor adalah umat dan sari telor adalah Alquran. Filosofi ini juga mirip denga tiga kerangka Agama Hindu yaitu: Tattwa, Etika/Susila dan 
Upacara. Kulit telor yang paling luar yang keras adalah upacara, putih telor adalah etika/susila dan sari telor adalah tattwa.

Fakta yang berkaitan dengan perayaan/upacara di atas berhubungan dengan keyakinan masing-masing komunitas. Hal ini sejalan dengan teori Simbol dari Langer (dalam Littlejohn \& Karena A, Foss, 2014:153), menyatakan simbol menggambarkan sesuatu yang in material, abstrak, suatu ide, kualitas, tanda-tanda suatu objek, yang dapat memberikan arahan bagi pikiran/perhatian yang mendorong untuk berinteraksi dalam mencapai tujuan. Dalam temuan penelitian yang terbingkai dalam kategori simbol khususnya yang berkaitan dengan keyakinan seperti: sokok base, sokok taluh. Telor (taluh) adalah produk lokal dari petani/peternak di Bali yang dalam konteks keyakinan masyarakat Desa Pegayaman "simbol telor" bermakna; kulit telor paling luar yang keras merupakan simbol dari masjid, putih telor adalah umat dan sari telor adalah Alquran. Masing-masing komponen memiliki makna: kulit telor paling luar yang keras merupakan simbol dari masjid alam Tuhan, putih telor adalah umat dan sari telor adalah Alquran (norma). Jadi perilaku budaya masyarakat di desa Pegayaman terbingkai dalam budaya. Tidak hanya dalam bentuk fisik tapi juga dalam bentuk interaksi budaya yang disebut dengan interaksi simbolik. Fakta ini dibenarkan berdasarkan George Herbert Mead yang dikutif oleh Morissan,2013, Santoso \& Mite Setiansah,2012, Littlejohn \& Karen A. Foss, 2014) menyatakan bahwa, interkasi simbolik adalah kehidupan sosial sebagai suatu proses interaksi yang diorientasikan dalam penampilan yang membentuk makna dan susunan dalam masyarakat melalui komunikasi.

Selanjutnya dapat dinyatakan bahwa segala hal yang saling berhubungan dengan pembentukan makna dari suatu benda atau lambang atau simbol, baik benda mati maupun benda hidup, melalui proses komunikasi baik sebagai pesan verbal maupun perilaku non verbal dan tujuan khirnya adalah memaknai lambang atau simbol (objek) tersebut berdasarkan kesepakatan bersama yang berlaku di wilayah atau kelompok komunitas masyarakat tertentu. Beberapa interaksi budaya pada masyarakat Desa Pegayaman seperti: Idul Adha, Maulid, mengarak sokok dan sejenisnya adalah berdasarkan pada teori interaksi simbolik merupakan simbol yang menyatakan ungkapan bathin, rasa syukur, atas kemenangan diri untuk mempertahankan nilai kebajikan/kebaikan melawan ketidak baikan. Demikian juga pada masyarakat Bali (Hindu) seperti haru raya Galungan dan lain-lain merupakan interaksi simbolik yaitu kemenangan Dharma melawan adharma. Secara ilmiah kegiatan-kegiatan spiritual masyarakat seperti, membuat hiasan sokok kemudian mengaraknya keliling desa dengan penuh suka cita dapat dipertanggungjawabkan berdasarkan teori interaksi simbolik ini. Maulid juga mempunyai makna upacara selamatan untuk desa yaitu mendoakan agar desa Pegayaman selamat dan memberi kesejahteraan bagi masyarakatnya, yang mana dalam perayaan ini selain mengarak sokok dengan berbagai jenis juga mengarak ogoh-ogoh (patung raksasa) yang sama persis ketika umat Hindu mengarak ogoh-ogoh saat perayaan Nyepi di Bali. Ogoh-ogoh saat Maulidan sama persis dengan ogoh-ogoh yang diarak umat Hindu menjelang Nyepi. Begitu pula dengan Seka (kelompok) Zikir yang melantunkan sejarah hidup Nabi dengan cara mekidung, adalah sama seperti yang dilakukan oleh umat Hindu dalam melantunkan mantera-mantera doa Hindu.

\section{d) Moderasi Beragama dalam Perspektif Keyakinan}


Moderasi beragama masyarakat Hindu-Islam di Desa Pegayaman divisualisasikan pada lambang desa. Pada lambang desa nampak dua gapura dalam budaya Bali disebut Apit Surang yang ditempatkan di sebelah kanan dan kiri Masjid. Dari penempatan simbol apit surang menunjukkan rasa persaudaraan yang akrab, harmonis dan selalu berdampingan dalam membangun desa. Apit surang adalah bangunan yang disakralkan oleh orang Bali (Hindu) yang bisanya digunakan pada setiap tempat suci (Pura). Ada juga yang ditempatkan di pintu depan rumah, dan pada pintu masuk gang atau jalan yang di dalamnya terdapat penduduk yang beragama Hindu. Simbol yang ada pada lambang desa Pegayaman juga bermakna sakral. Menurut masyarakata desa Pegayaman mereka melihat kesakralan tersebut dari bentuk gapura (apit surang) yang mempunyai tiga tingkatan yaitu: bagian bawah, tengah dan atas. Dalam konsep Hindu tiga tingkatan tersebut bermakna: Bhur (alam bawah), Bhuah (alam tengah) dan Swah (alam atas). Namun keyakinan masyarakat Muslim di desa Pegayaman menyebut sebagai Tri Hita Karana yang terdiri dari: Islam (Parhyangan $=$ hubungan manusia dengan Tuhan), Iman (Pawongan = hubungan manusia dengan manusia) dan Ihsan (Palemahan = hubungan manusia dengan mahluk lainnya). Disamping keyakinan atas konsep Tri Hita Karana masyarakat Muslim desa Pegayaman juga mengenal konsep kepemimpinan Asta Bhaharata. Dalam konsep Hindu Asta Bhaharata adalah delapan sifat kepemimpinan Hindu, namun Asta Bhaharata menurut pandangan masyarakat desa Pegayaman bermakna delapan orang prajurit Belambangan / Mataram masuk ke desa Pegayaman dan prajurit tersebut memiliki sifat Asta Bhaharata. Simbol Asta Bharata dinyatakan dalam lambang Gelung Hias yang ditempatkan di bawah atap Masjid berjumlah delapan (Profil Desa Pegayaman, 2015). Tuhan menciptakan alam/dunia dengan segala isinya, tetapi manusia mampu menciptakan ide/konsep/kebudayaan. Simbol seperti profil Desa Pegayaman adalah hasil cipta manusia. Hasil cipta tersebut memiliki makna yang diyakini oleh masyarakat akan dapat memberikan memberikan tuntunan mencapai tujuan. Seperti konsep apit surang,dan Asta Bharata memiliki makna filosofi kehidupan khususnya bagi masyarakat Desa Pegayaman. Seperti temuan penelitian di atas dapat terungkap di balik teori sistem keyakinan yang ditulis oleh Koentjaraninggrat, (2009) menyatakan bahwa, sistem keyakinan dalam suatu religi berwujud pikiran dan gagasan manusia yang menyangkut keyakinan dan konsepsi manusia tentang sifat-sifat Tuhan, tentang wujud alam gaib, dunia akhir, roh nenek moyang, dewa-dewa, hantu serta sistem nilai, sistem norma, kesusilaan, dan doktrin religi lainnya yang mengatur tingkah laku manusia. Sistem keyakinan tersebut biasanya terkandung dalam kesusastraan suci, baik yang tertulis maupun lisan, seperti dongeng dan mitologi. Keyakinan merupakan pengorganisasian konsep kognitif, misalnya individu memegang keyakinan yang dapat dibuktikan melalui kejadian yang dapat dipercaya, tradisi rakyat atau keluarga merupakan keyakinan yang berjalan dari satu generasi ke generasi yang lain. Berdasarkan teori di atas simbol apit surang yang ditempatkan di sebelah kanan dan kiri Masjid bermakna persaudaraan (memiliki tata nilai, norma sosial, kekuatan gaib), sedangkan dalam kontek Bali Hindu bermakna Rwabhineda yang tidak dapat dipisahkan. Apit surang adalah hasil cipta masyarakat yang disepakati sebagai produk budaya leluhurnya. Secara kognitif masyarakat Desa Pegayaman juga mempersepsi/meyakini bahwa apit surang menggambarkan tiga tingkan alam yaitu: alam bawah, tengan dan atas. Dalam konsep Hindu adalah Bhur, Bhuah dan Swah. Kesamaan konsep merupakan proses kohesivitas (keintiman/kekuatan pengaruh budaya) akulturasi (penggabungan budaya). Dalam kontek akulturasi Hindu-Muslim nampak hanya pada ranah pola/model namun berbeda dalam ranah keyakinan. 
Jurnal Widya Sastra Pendidikan Agama Hindu, Vol 4, No. 1, 2021

ISSN: 2656-7466

\section{e). Moderasi Beragama Dalam Perspektif Budaya Berkomunikasi}

Desa Pegayaman dihuni oleh masyarakat yang mayoritas penduduknya memeluk agama Islam, namun berada di wilayan Kabupaten Buleleng, Provinsi Bali yang juga mayoritas berpenduduk Agama Hindu. Di Kabupaten Buleleng banyak juga Desa dalam satu RT/RW dominan beragama Islam, namun, di Desa Pegayaman sangat berbeda, mereka punya ciri khas yang membedakannya dengan umat muslim di tempat lain. Menurut penuturan dari beberapa responden (masyarakat Desa Pegayaman) menyebutkan, warga muslim Pegayaman dalam pergaulannya tetap memakai anggah-ungguh bahasa Bali baik dalam pergaulan interen warga maupun dengan warga Bali di sekitarnya. Tidak hanya dalam pergaulan informal, di sekolah juga guru menggunakan bahasa Bali sebagai pengantar pelajaran khususnya untuk kelas rendah (Kelas I, II). Bahasa Bali yang digunakan adalah bahasa Bali madya dan bahkan bahasa Bali alus. Penutur bahasa Bali tidak hanya orang tua anakanak pun menggunakan bahasa Bali. Mata pelajaran bahasa Bali juga masuk dalam kurikulum sekolah. Toleransi ke dua pihak juga nampak pada perayaan hari-hari besar seperti Idul Adha untuk umat Muslim dan hari raya Galungan dan Kuningan untuk umat Hindu. Pada hari raya Idul Adha masyarakat Muslim Desa Pegayaman sering memasang penjor, yaitu bambu berhias yang ditancapkan di depan rumah tetapi tidak disertai dengan sesajen. Dalam pembuatannya, warga Hindu ikut membantu, menghias, sampai memancangkannya. Demikian sebaliknya Bila warga Hindu menyongsong hari suci Nyepi, warga muslim beramai-ramai membantu mengusung ogoh-ogoh, yang dibuat sehari menjelang Nyepi. Mereka juga ikut menghormati perayaan "Nyepi" dengan cara menghentikan kegiatan sehari-hari, dan hanya berdiam di rumah.

Dilihat dari persfektif berkomunikasi, maka hubungan inter dan antar umat beragama sangat saling menghargai, sangat bertoleransi, dan bukan saja seperti itu tetapi intensitas komunikasinya sangat akrab, persaudaraannya sangat erat dan rasa persatuannya sangat inten sehingga moderasi beragama menyamabraya-nya hampir sempurna. Hal ini memenuhi syarat sebagai masyarakat yang betul-betul kohesif, yakni: (1) ada kekuatan interaksi dari anggota suatu kelompok, (2) ada keramahtamahan antar anggota kelompok dan senang untuk bersama-sama, (3) anggota merasa bebas untuk mengemukakan pendapat dan sarannya, (4) anggota kelompok biasanya juga antusias terhadap apa yang ia kerjakan dan mau mengorbankan kepentingan pribadi demi kepentingan kelompoknya, (5) merasa rela menerima tanggung jawab atas aktivitas yang dilakukan untuk memenuhi kewajibannya, (6) menunjukan adanya kesatuan, keeratan, dan memiliki daya tarik untuk tetap dalam kelompok atau kesatuan, dan (7) punya waktu untuk bersamasama pada saat-saat tertentu. Sedangkan unsur-unsur menyamabraya-nya dilihat dari persfektif komunikasinya, ada tradisi bagus yang cenderung dipelihara antara lain: saling bantu membantu/gotong royong dalam sarana jalan, alat transfortasi, bercocok tanam di kebun atau sawah, beternak, saling kunjung mengunjungi saat hari raya agama masing-masing, saling memberi dan menerima ide-ide, dan juga termasuk di bidang sandang dan pangan. Masyarakat Pegayaman sudah berhasil menanamkan pointer-pointer penting yang terkandung dalam istilah "menyamabraya" itu antara lain: (1) ada hubungan yang akrab, intensif dan koheren dalam sebuah kelompok/komunitas, (2) hubungan tersebut terjadi diikat oleh adat, tradisi dan 
Jurnal Widya Sastra Pendidikan Agama Hindu, Vol 4, No. 1, 2021

ISSN: 2656-7466

budaya, (3) tercipta suasana aman, damai dan harmonis, (4) ada kerjasama, ada rasa sama.

\section{f). Moderasi Beragama Dalam Perspektif Personal (Identitas Diri)}

Mereka juga senang memakai bija (biji beras sebagai tanda menanam biji kebaikan) di keningnya seperti orang Bali, dan pada identitas diri menggunakan nama depan yaitu: wayan/putu, made/nengah, nyoman dan ketut namun anak yang ke lima balik lagi menggunakan wayan/putu. Demikian juga halnya bagi saudara Muslim di Desa Pegayaman, budaya yang dianutnya yaitu budaya Bali nampaknya juga berpengaruh terhadap identitas personalnya. Hal ini ditunjukkan pada nama depan mereka yaitu menggunakan predikat: wayan/putu, made/nengah, nyoman dan ketut. Pemberian nama depan adalah contoh akulturasi budaya lainnya sebagai penciri identitas diri. Sebagai orang Bali, warga desa Pegayamanpun menggunakan nama depan Wayan/putu, Nengah/made, Nyoman, dan Ketut. Namun nama belakang mereka biasanya Bahasa Arab. Identitas mereka sebagai orang Bali muslim dipertahankan untuk meningkatkan kohesivitasnya, kesetiaannya dan toleransinya terhadap umat Hindu Bali di desa Pegayaman dan di luar desa Pegayaman. Dijelaskan bahwa sampai saat ini masyarakat Desa Pegayaman masih tetap menggunakan nama depan: wayan/putu untuk anak pertama, nengah/made untuk anak yang kedua, nyoman untuk anak yang ketiga, ketut untuk anak yang ke empat. Sedangkan anak yang ke lima dan seterusnya tetap menggunakan nama depan ketut. Tidak seperti di Bali anak kelima adalah (wayan balik). Tidak hanya itu ada juga menambahkan ayu setelah nama depan seperti; Putu Ayu Maziyya (Putri dari bapak Sekdes). Penggunaan nama depan yang sama persis dengan orang Bali (Hindu) sudah diwarisi dari leluhur mereka secara turun-temurun. Ini menunjukkan bahwa mereka mewarisi budaya Bali karena mereka adalah orang Bali. Budaya merupakan alasan yang paling kuat sebagai dasar mengapa masyarakat Muslim Desa Pegayaman menggunakan identitas wayan, nengah/made dan seterusnya. Masyarakat muslim Desa Pegayaman sangat patuh dan taat pada budaya, karena kapatuhan dan melaksanakan budaya warisan leluhur dapat memberi kedamaian, kenyamanan dalam kehidupan mereka. Sejalan dengan perkembangan jaman di era globalisasi ini identitas nama budaya Bali tersebut masih tetap eksis. Hal tersebut diperkuat dari pernyataan responden bahwa sebagian besar atau hanya sebagian kecil saja masyarakat Muslim Desa Pegayaman yang tidak menggunakan identitas nama Bali di depan nama mereka. Masyarakat yang tidak menggunakan identitas nama Bali di depan namanya, biasanya mereka pendatang dari Jawa atau sudah sedikit kena pengaruh jaman yang cenderung meniru nama orang terkenal atau bintang sinetron/film namun tidak dijelaskan secara rinci siapa-siapa masyarakat yang tidak menggunakan nama depan Bali.

Pemakaian nama depan budaya Hindu Bali oleh umat Muslim di desa Pegayaman, dapat pula bermakna sebagai wujud kohesivitas mereka me-nyamabraya, sehingga mereka tidak merasa berbeda, bisa luluh dengan segera dalam situasi dan kondisi tertentu, dapat berbaur dengan cepat dan tidak pernah memandang perbedaan di antara mereka masing-masing. Hal ini secara implisit dapat menetralisir konflik SARA, apalagi setelah dipahami tentang konsep "menyama-braya" sangat efektif sebagai senjata untuk mempersatukan SARA. Bahasa menyama-braya adalah Bahasa Bali, yang mengandung makna ada saling hubungan yang intensif dan koheren di antara 
komunitas warga yang diikat oleh tradisi, adat dan budaya. Menyamabraya adalah konsep ideal hidup bermasyarakat di Bali sebagai filosofi dari karma marga yang bersumber dari sistem nilai budaya dan adat istiadat masyarakat Bali untuk dapat hidup rukun. Kerukunan mengandung makna akrab, damai dan tidak berseteru, diibaratkan pada kehidupan sepasang suami istri dalam rumah tangga yang harmonis dan damai seperti yang dijelaskan dalam menghormati kearifan lokal sebagai landasan strategis mewujudkan makna menyama-braya sebagai penguatan jati diri bangsa, hendaknya menyadari bahwa manusia itu tidak hidup sendiri di dunia ini, tetapi dalam komunitasnya, masyarakatnya, dan alam semesta sekitarnya. Manusia pada hakikatnya tergantung dalam segala aspek kehidupannya kepada sesama umat manusia, karena itu ia selalu berusaha untuk sedapat mungkin memelihara hubungan baik, terdorong oleh jiwa sama rata sama rasa; dan selalu berusaha untuk sedapat mungkin bersifat konform, bekerjasama dalam komunitasnya. Beberapa konsep kunci yang dipegang teguh di Bali sebagai pedoman di dalam hubungan antara manusia dengan manusia antara lain konsep Tat Twam Asi dan Yama Niyama Brata.

\section{KESIMPULAN}

Moderasi adalah suatu sikap untuk tidak berlebihan dalam menghadapi problematika kemajemukan. Sikap itu bukanlah sikap pasif dan statis, dengan hanya mengendalikan kemajemukan agar tidak menjadi ekses negatif berupa perpecahan dan keretakan. Lebih dari itu, sikap moderasi itu bersifat aktif dan dinamis, dengan adanya cita-cita sosial yang ingin diperjuangkan, yaitu cita- cita melakukan perubahan sosial ke arah yang positif dan ke arah yang lebih baik. Secara bahasa, moderasi berasal dari bahasa Inggris, moderation yang memiliki arti sikap sedang, sikap tidak berlebih-lebihan. Jadi, moderasi beragama adalah proses memahami sekaligus mengamalkan ajaran agama secara adil dan seimbang, agar terhindar dari perilaku yang menyimpang yang tidak ada di ajarkan di dalam agama.

Pengenjawantahan moderasi beragama dalam kehidupan bermasyarakat dapat memunculkan akulturasi budaya seperti yang terdapat di Desa Pegayaman. Akulturasi budaya adalah bertemunya dua atau lebih kebudayaan yang berbeda melebur menjadi satu menghasilkan kebudayaan baru tetapi tidak menghilangkan kepribadian/sifat kebudayaan aslinya. Terkait dengan penelitian ini moderasi beragama dapat dilihat dari dua budaya yang berbeda yaitu budaya Bali (Hindu) dan budaya Islam (Muslim) di Desa Pegayaman. Budaya Bali bagi orang Bali bersumber dari Agama Hindu yang tercermin dalam setiap segi kehidupan sehari-hari. Demikian juga bagi masyarakat di Desa Pegayaman, Agama Islam yang dianutnya menjadi dasar perilaku mereka. Oleh karena itu interaksi antara kedua kebudayaan tersebut memberi warna khusus bagi masyarakat pegayaman. Berdasarkan hasil analisis diperoleh bahwa moderasi beragama di Desa Pegayaman dapat dilihat berbagai unsur aktivitas masyarakat yaitu: moderasi beragama dalam perspektif pemerintahan desa, moderasi beragama dalam perspektif kepemimpinan, moderasi beragama dalam perspektif upacara persembahan, moderasi beragama dalam perspektif keyakinan, moderasi beragama dalam perspektif budaya berkomunikasi, moderasi beragama dalam perspektif personal, moderasi beragama dalam perspektif budaya dan seni, moderasi beragama dalam perspektif tradisi ngejot. 


\section{DAFTAR PUSTAKA}

Astika, Ketut Sudhana, I Wayan Suwena \& Ni Nyoman Ayui Candradewi. 1986.

Peran Banjar Pada Masyarakat Bali. Jakarta: Depdikbud. Proyek Inventarisasi dan Dokumentasi kebudayaan daerah.

Bogdan,R.C. \& Taylor, S.J., (1973), Inroduction to Qualitative Research Methods, A Phenomenological Approach to the Social Science, New York: John Wiley \& Sons.

Bungin, Burhan. 2003. Analisis Data Penelitian Kualitatif (Pemahaman Filosofis dan Metodologis ke Arah Penguasaan Model Aplikasi, Jakarta: PT. Rajagrapindo Persada).

Depdiknas. 2000. Kamus Besar Bahasa Indonesi, edisi ketiga. Jakarta. Koentjaraningrat, 2009. Pengantar IImu Antropologi. Jakarta: Rineka Cipta.

Landrawan, I Wayan, dkk. 2013. Menyama Braya dalam Masyarakat Islam dan Hindu di Desa Pegayaman Kecamatan Sukasada Kabupaten Buleleng. Singaraja: http://download.portalgaruda.org/

Littlejohn, Stephen W. \& Karena A. Foss. Teori Komunikasi. Terjemahan Mohammad Yufuf Hamdan.Theories of Human Communication $9^{\text {th }}$ ed. Jakarta: Salemba.

Morgan, David L., 1997, Focus Group as Qualitatif Research, London, Sage Publication.

Morissan. 2013. Teori Komunikasi Komunikator, Pesan, Percakapan dan Hubungan (Interpersonal). Jakarta: Ghalia Indonesia

Ngurah, I Gusti Made. 2010. Saling Menerima Dan Menghargai Perbedaan Melalui Dialog Antar Umat Beragama Dalam Masyarakat Multikultural. Denpasar: Yayasan Sari Kahyangan Indonesia.

Perbekel Pegayaman. 2015. Peropil Desa Pegayaman Kecamatan Sukasada Kabupaten Buleleng Bali.

Santoso, Edi \& Mite Stiansah. 2012. Teori Komunikasi. Jogyakarta: Graha IImu.

Schneiders, Alexander. 1964. Personal Adjustment and Mental Health. New York: Hoolt, Rinehart and Winston.

Strauss, Anselm I dan Yuliet Corbin, 1990, Basic of Qualitative Research : Grounded Theory Procedures and Techniques, California : Sage Publications.

Suarnaya, I Putu. 2002. Adat Istiadat dan Organisasi Sosial (Muatan Lokal untuk SLTP kelas 3). Denpasar: Putra Bali.

Sugiyono, 2012. Metode Penelitian Kuantitatif, Kualitatif, dan Kombinasi 
Jurnal Widya Sastra Pendidikan Agama Hindu, Vol 4, No. 1, 2021 ISSN: 2656-7466

(Mixed Mothods), Bandung, Penerbit Alfa Beta.

Triguna, Yudha IBG (ed).2008. Kebudayaan dan Modal Budaya Bali Dalam Teropong Lokal Nasional Global. Denpasar: Widya Darma.

Yukl, Gary. 2010. Kepemimpinan Dalam Organisasi. Terjemahan Budi Supriyanto Leadership in Organization. 2001. Jakarta: PT. Indeks. 